\title{
Introduction: A Past of Her Own: History and the Modernist Woman Writer
}

\author{
MARK LLEWELLYN and ANN HEILMANN \\ (Guest Editors)
}

The articles collected in this special issue were originally all delivered as papers at the 'Hystorical Fictions: Women, History and Authorship' conference we organised at the University of Wales, Swansea, in August 2003. When we began planning the event - writing the call for papers; contacting academics we thought might be interested in attending - we anticipated that, given the recent prominence of 'historical fiction' by authors such as A. S. Byatt, Tracy Chevalier, Rose Tremain, Sarah Waters, Jeanette Winterson and others, a large number of speakers would want to focus on contemporary women writers' uses of history. What proved most interesting, however, was the way in which this trend of, to use Adrienne Rich's term, feminist 're-visioning', ${ }^{1}$ viewed by so many critics and readers as part of a postmodern literary culture, has its roots in the modernism of the early twentieth century.

The modernist movement is generally viewed as holding the twin imperatives of moving into the future while addressing the continued presence of the past and of tradition. T. S. Eliot, who built his quintessentially modernist text The Waste Land on the foundations of the traditional literary canon, declared in his essay 'Tradition and the Individual Talent' that for the male artist and poet 'the most individual parts of his work may be those in which the dead poets, his ancestors, assert their immortality most vigorously ... His significance, his appreciation is the appreciation of his relation to the dead poets and artists' ${ }^{2}$ History and literary tradition are thus the cornerstones of high modernism.

Yet while the relationship of male modernist writers like Eliot, Joyce and Yeats with history and (literary) tradition has been the subject of much critical discussion, ${ }^{3}$ and although seminal feminist work of the last two decades has established the significance of 
women's writing for the modernist imagination, ${ }^{4}$ the interaction of women modernists with the past remains an underexplored area. The articles in this special issue are unified by a desire to explore how women writers of the modernist period used, adapted, experimented with and exploded traditional (literary) history in their work. This involves tracing connections and 'cross-correspondences' with literary paradigms of the preceding (Victorian and Edwardian) eras. Placing new interpretations of key female modernists like Virginia Woolf and H. D. alongside work on less well charted authors like Josephine Herbst or neglected novels like Vita Sackville-West's The Edwardians, this special issue emphasises the modernist woman writer's engagements with and reconceptualisations of history in her work.

The issue opens by returning to the beginnings of the modernist aesthetic in the work of Vernon Lee. Patricia Pulham's article on Lee's short story 'A Wedding Chest' provides a stimulating account of her fascination with ghostly figures transgressing the boundaries between present and past and between hetero- and homosexual desires. By setting her work in the Renaissance, Pulham argues, Lee manages to open up a Winnicottian 'potential space' where sexual identity can be negotiated and where the desire for the mother's body can be satiated. The 'otherness' of the past is essential to this process, and yet it is also about concerns of the immediate present.

From the metaphorical and archival ghostliness of a re-imagined Renaissance history, we move to the realm of authorial ghosts and the late-Victorian and Edwardian fascination with the séance, psychical research and automatic writing. Exploring the work of the Society of Psychical Research (SPR) at the start of the twentieth century, Leigh Wilson's article provides close readings of the automatic writing scripts, subsequently referred to as the 'cross-correspondences', which were generated by several female mediums from 1901. These scripts prove interesting not only because of their complex intertextuality, but also through their gendered authorship. Although ostensibly communicated from the spirits of prominent, deceased, male members of the SPR, it was through female spiritualists that the texts were transmitted to the society.

While the ghostly writing appearing within the SPR caused problems because of its interjection of female spirituality and mediumship into the male arena, it is the very problem of the written word and its inscription which lies at the heart of Sarah Dillon's contribution. Dillon examines H. D.'s prose work Palimpsest (1926), 
a complex web of genres, periods and voices connected by the sense in which each text is overwritten or overwrites another. The palimpsest motif, and the sense in which these texts exist in a simultaneous para- or intertextual relationship with one another, suggest an undermining of conventional understandings of not only narrative time but also chronological history. Different and yet occupying the same material space, the three stories within H. D.'s text offer a female-centred narrative which embodies at one and the same moment a sense of tradition and modernity intertwined.

No journal issue devoted to the modernist woman writer could avoid the haunting presence of the work of Virginia Woolf, and Abby Bardi's article shows the way in which Woolf herself may have found her textual engagements with the figure of the Gypsy ghosted by the presence of Charlotte Brontë. In an interesting comparative analysis, Bardi suggests that Woolf's use of the trope of the Romany or Gypsy in Orlando is influenced by the gender instability of this figure in nineteenth-century literature.

The 'queering' of gender discourse in Woolf's Orlando also provides the focus of Alison Winch's article on the connections between Sappho, Lady Mary Wortley Montagu and Woolf's hero/ine. Exploring the issues of the lesbian gaze, autoeroticism and crossdressing in Montagu's works, Winch suggests that Woolf's portrayal of her rescues her reputation from the imposition of rigid gender categories and the constraints of the male gaze exerted by writers such as Pope. Woolf's aim in this process of re-visioning is nothing less than the creation of a living female tradition and a community of women writers freed from the strictures of linear notions of time, space and place in the formulation of female identity.

The association between men and the presentation of history is also explored by Jane de Gay. In her interpretation of Orlando, de Gay argues that Woolf's games with time and historiography in her novel are a direct undermining of Leslie Stephen's patriarchal understanding of these terms. Woolf's novel thus becomes a feminist historian's text in the sense that it parodies the certainties of the predominantly male, historiographic worldview. If Woolf's Orlando, according to de Gay's reading, makes the historical personal, then Sophie Blanch's interpretation of Vita Sackville-West's novel The Edwardians echoes this in asserting a political, social and economic reading of familial relationships based on a patrilineal inheritance structure. Blanch reads Sackville-West's text as both an engagement with the potential 
liberation to be found in Woolf's history (as presented in Orlando) and a reassessment of prevalent attitudes amongst Edwardian high society from the perspective of an early 1930s politics. The Edwardians thus benefits from an historical double-sightedness which, in its own way, complements the kinds of historicist reinterpretations found in the work of Lee, H. D. and Woolf.

Our final essay moves location to the United States and the work of Josephine Herbst, and reveals intriguing challenges to male modernist authors' theories of a chaotic contemporary landscape. Herbst, in seeking to reformulate the past in order to reconstitute the present was, Angela Hubler argues, asserting a contrast to the Eliotic vision of a feminised, emasculated modern world which threatened the subject's identity.

Although the voice of Virginia Woolf lies at the heart of this issue, the articles gathered here reveal both how she developed from an earlier tradition - found in the work of women like Lee - and how her challenges to male dominance in the fields of literature and history inspired others to (re-)imagine a female modernist space. For Joyce's Stephen Daedalus, history was the nightmare from which he was trying to awake; for Woolf and other women of the modernist period, it was a nightmare which they were willing to rewrite.

\section{Notes}

1. Adrienne Rich, 'When We Dead Awaken: Writing as Re-Vision' [1971], in Adrienne Rich's Poetry, ed. Barbara Charlesworth Gelpi and Albert Gelpi (New York: Norton, 1975), 90-98.

2. T. S. Eliot, 'Tradition and the Individual Talent' [1919], in Modernism: An Anthology of Sources and Documents, ed. Vassiliki Kolocotroni, Jane Goldman and Olga Taxidou (Edinburgh: Edinburgh University Press, 1998), 366-371 (367).

3. The most clear example of this would be Malcolm Bradbury and James McFarlane's edited collection Modernism: A Guide to European Literature, 1890-1930 (Harmondsworth: Penguin, 1991 [1974]) which is largely male-centred in terms of coverage (only four women writers receive entries in the 'Brief Biographies' section) and critics (one woman).

4. See, for example, Sandra M. Gilbert and Susan Gubar, No Man's Land: The Place of the Woman Writer in the Twentieth Century: Volume 1 The War of the Words (New Haven: Yale University Press, 1988), and Bonnie Kime Scott, ed., The Gender of Modernism: A Critical Anthology (Bloomington: Indiana University Press, 1990) which is dedicated to 'the forgotten and silenced makers of modernism'. 